\title{
Factors Affecting Export Performance Indonesian Fashion Creative Industry
}

\author{
Tedjo Asmoro ${ }^{1}$ Rodoni $^{2}$, Meirinaldi $^{3}$ \\ \{asmara.ojet@yahoo.co.id ${ }^{1}$,rodoni@borobudur.ac.id ${ }^{2}$, meirinaldi.2505@gmail.com 3 \} \\ Universitas Borobudur, Jakarta, Indonesia ${ }^{1,2,3}$
}

\begin{abstract}
The background of this research is the fashion industry in Indonesia is currently growing very rapidly. This is in line with the awareness of the Indonesian people about fashion that leads to a lifestyle. The fashion industry is still one of the largest foreign exchange earners and dominates the export portion for the creative economy sector. The purpose of this research is to determine and analyze the impact of the rupiah exchange rate, the fashion industry's number, inflation, banking credit, and tourism on the export performance of creative industry items in the fashion industry. The research method used in this study is Ordinary Least Square Multiple Linear Regression / simple. The data used is a time series from 2010 to 2020 with quarterly data. The novelty of this study is that the number of fashion industries is the most dominant variable affecting the export performance of the fashion industry compared to other variables. This shows how important it is for this sector to continue to grow and develop in massive numbers. The results showed that (1) the rupiah exchange rate, the number of the fashion industry, inflation, banking credit and tourism had a significant and positive effect both simultaneously and partially on the export in the fashion industry, the performance of creative industry products, (2) the export performance of creative industry products in the fashion sector significant and positive effect on Indonesia's trade balance.
\end{abstract}

Keywords: Creative Industry in Fashion; Rupiah Exchange Rate; Inflation; Bank Credit; Tourism; Indonesia's Trade Balance

\section{Introduction}

Law Number 24 of 2019 concerning the Creative Economy/Industry regulates the optimization of human resource creativity based on cultural heritage, science, and/or technology. Through the development of a Creative Economy Ecosystem that provides added value to Creative Economy products that are highly competitive, it is easily accessible and legally protected. The definition of the creative economy by INDEF (2018) is a process that provides additional value from the exploitation of intellectual property in the form of expertise and creativity from individuals that is manifested into a product or work that can be sold or has a selling value.

Meanwhile, according to the description delivered by the DCMS Creative Industries Task Force (2019) regarding the creative industry is creativity or expertise including the talent of a 
person or individual who has or has the opportunity to get wealth and even create jobs through the exploitation or development of intellectual property and content. In practice, the creative economy sector has proven to be a new source and strength of the economy. While slowing global commodity and raw material prices, the creative economy sector has made a positive contribution to the Indonesian economy. Based on the latest data, the creative economy contributes 7.38 percent to the total national economy with an entire GDP of around Rp. 852.24 Trillion. Of this total contribution, the culinary, craft, and fashion sub-sectors make the largest contribution to the creative economy. The Culinary sub-sector contributed $41.69 \%$, followed by the Fashion sub-sector at $18.15 \%$ and Crafts at $15.70 \%$.

Industrialization creates a pattern of work, production patterns, and distribution patterns that are less expensive and more effective. People are becoming more active and productive in discovering new technologies as a result of advances such as discoveries in the field of information and communication technology, such as the internet, email, Google PlayStore, and so on. The growth of enhanced competitiveness or market competition is one of the consequences of this wave change phenomena. To stay afloat in this environment, businesses must discover ways to cut costs as cheaply and efficiently as possible. Developed countries are beginning to see that they cannot solely rely on the industrial sector as an economic resource in their country at this time, but must also rely on creative human resources, because human creativity is based on the power of thought is the primary capital to create innovations in the face of competitiveness, or increasing market competition.

\subsection{Problem Identification}

a. The fashion industry, especially in the MSME sector, is generally located in the fashion industry which until now has not been able to optimally develop in creating unique resources.

b. The national fashion industry faces problems with the flood of imported fashion products and the smuggling of used clothes (ball press). These problems have threatened the sustainability of the domestic fashion industry which has an impact on the decline in utility, market share, and competitiveness in the domestic market.

c. The creative industry in the fashion sector in the MSME sector is still not maximally able to establish industrial cooperation with various relevant stakeholders because there are still many who do not have a clear legal entity.

d. The fashion industry is experiencing an existential crisis during 2020 .

e. The chaotic economy due to the pandemic has made consumers cut back on spending on fashion. It occurs naturally in an attempt to survive.

f. Fluctuations that occur in the export level of the fashion industry can occur due to several factors related to exports, one of which is the exchange rate of the rupiah against the United States dollar.

g. The weakening of the rupiah exchange rate was due to the spread of the Covid-19 pandemic throughout the world, including Indonesian led to an increase in the risk of global uncertainty so that investors tended to shift their investment funds to safe-haven assets, such as gold, government bonds of developed countries, and world currencies, such as United States dollars.

h. Inflation causes goods produced by the fashion industry being unable to compete in the global market It is because the price of domestic goods has increased so that producers are not able to produce optimally. 
i. The Covid-19 pandemic has disrupted the inflation pattern in Indonesia where the movement of inflation has left its trend as happened in 2019 and experienced inflation of minus $0.1 \%$ aka deflation.

j. For start-up fashion industry companies, the obstacle faced in applying for bank credit is collateral or collateral is difficult to fulfill because the size of collateral applied by banks is different from that of startup companies.

k. The COVID-19 pandemic has made banks selective in distributing financing for the creative industry sector, especially in the fashion industry. The reason is, the turnover of the MSME creative industry during the pandemic has greatly decreased and then affects the smoothness of bank credit.

1. Although it influences the exports of the Indonesian fashion industry, the tourism role has not been optimized to encourage the export performance of the fashion industry.

m. With the Covid 19 pandemic, the number of foreign tourist visits throughout 2020, recorded only 3.5 million visits, a decline of up to $70.57 \%$ due to many countries still prohibiting their citizens from traveling and must maintain health.

\subsection{Research Problem}

a. What is the effect of the rupiah exchange rate, the number of fashion industries, inflation, banking credit, and tourism on the export of creative industry products in the fashion sector?

b. How is the effect of the rupiah exchange rate on the export of creative industry products in the fashion sector?

c. How does the number of fashion industries affect the export of creative industry products in the fashion sector?

d. How does inflation affect exports of creative industry products in the fashion sector?

e. What is the effect of bank credit on the exports of creative industry products in the fashion sector?

f. How is the influence of tourism on the export of creative industry products in the fashion sector?

\section{Materials and Methods}

\subsection{Creative Economy}

The term creative economy evolved from the concept of creativity-based capital that could potentially increase economic growth in an area. According to President Susilo Bambang Yudhoyono in Agung Pascasuseno (2014), "the creative economy is the fourth wave of the economy which is a continuation of the third wave of the economy with an orientation to creativity, culture, and cultural and environmental heritage". The creative economy, which includes the creative industry, is currently believed to be able to contribute significantly to the nation's economy. Indonesia has also begun to see that various sub-sectors in the creative industry have the potential to be developed because the Indonesian nation has creative human resources and rich cultural heritage.

According to Howkins (2011), the creative economy is based on new ways of thinking and doing. The main input is our talent or skill [1]. That input may sound familiar but what is more important is that our creativity transforms it in new ways. According to the Ministry of Trade 
of the Republic of Indonesia, a Creative economy is an industry that originates from the utilization of individual creativity, skills, and talents to create prosperity and employment opportunities by generating and empowering the creative power and creativity of the individual. According to UNCTAD and UNDP in the Creative Economy Report (2010), the creative industry economy can be defined as a cycle of creation, Creative and intellectual capital are the primary inputs in the production and distribution of products and services [2].

The creative industry is made up of a diverse field of activity-based knowledge that produces real and non-real intellectual goods or artistic services with creative content, ranging from traditional arts and crafts, publishing, music, visual, and art formation to the extensive use of technology and group-based services like film, television, and radio broadcasting, as well as new media and design. The although the creative economy and the creative industry are closely related, the creative economy has a greater reach than the creative industry. The creative economy is an ecosystem in which the creative value chain, development environment (nurturance environment), market, and archiving are all interdependent.

Core creative industry is a creative industry whose majority added value creation is the utilization of the creativity of creative people. The core creative industry requires the product of other industries as input in the process of developing added value. The backward linking creative industry is the industry that becomes the input for the core creative industry. The forward linking of the creative industry refers to the ability of the core creative sector's product to be used as input for other industries. In the creative economy, the creative industry is a driving factor for value creation. In the process of creating creative value, the creative industry does not only create economic transactions, but also social and cultural transactions. The general process which occurs in the creative value chain is creation-productiondistribution-commercialization, but each creative industry group has a different creative value chain [3].

\subsection{International Trade}

Each country has distinct qualities, resources, economies, and societies from others. As a result of these variances, the commodities produced in each country differ. A country may require a commodity that it cannot produce but can be obtained from another country. As a result, each country cannot stand alone and requires the assistance of others. That is the reason for international trade [4]. According to Ruin (2008), the exchange of commodities and services between countries is known as international trade [5]. This view is nearly identical to Seyoum's (2014) understanding, namely the exchange of goods and services across national borders [6]. It happens because each country and its trading partner countries have several differences, including differences in the content of natural resources, climate, population, human resources, labor specifications, geographical configuration, technology, price levels, economic, social, and political structures, and so on.

From these differences, based on mutually beneficial needs, an exchange process occurs which on a broad scale is known as international trade. Suranovic (2010) states that five basic countries are conducting international trade, namely; Differences in technology, differences in resources, differences in demand, economies of scale in production, government policies [7]. International trade theory helps explain the direction and composition of trade between countries and how they affect a country's economy. In addition, international trade theory can also show the benefits arising from international trade (gains from trade). 


\subsection{Export Theory}

Export is defined as the removal of items from within and beyond a country while adhering to all applicable restrictions. The gains received from overseas trade interactions are what drive a country's exports. Trade may also help a country's consumption capacity grow, as well as assist various firms in developing and expanding the role of sectors that have a comparative advantage due to efficiency in production component. The definition of export according to the Decree of the Minister of Industry and Trade Number 182/MPP/Kep/4/1998 concerning General Provisions in the Export Sector, states that export is the activity of removing goods and services from the customs area of a country. The customs area is defined as the territory of the Republic of Indonesia which includes land, waters, and air space above it, as well as certain places in the exclusive economic zone and continental shelf in which Law No. 10 of 1995 concerning Customs applies.

Exports are various kinds of goods and services produced domestically and then sold abroad [8]. In terms of expenditure, exports are one of the foremost factors of Gross National Product (GNP), so that with changes in the value of exports, people's incomes will directly experience changes. On the other hand, the high exports of a country will cause the economy to be very delicate to shocks or fluctuations that occur in the international market and the world economy [9]. According to the version of the Central Bureau of Statistics (BPS), it says that the export of goods is all goods brought out of the territory of a country, both commercial and non-commercial (grants, donations, gifts), as well as goods to be processed abroad and the results are imported as a return to the country. As for what is not included in the export category, among others, clothing, personal items and jewelry belonging to passengers traveling abroad, goods sent for representatives of a country abroad, goods for expeditions/exhibitions, containers to be refilled, money and securities, and goods for example.

According to Mudrajad Kuncoro (2015) adherents of an open economic system, international trade traffic plays an important role in the economy and development in Indonesia is how far the role of foreign trade can be seen from the ratio between exports plus imports to GDP [10]. According to Todaro (2018), exports are international trade activities that provide a stimulus to grow domestic demand which leads to the growth of large manufacturing industries, along with a stable political structure and flexible social institution [11]. In other words, exports reflect international trade activities, so that a developing country is likely to achieve economic progress on par with more developed countries.

Export is the process of legally transporting goods or commodities from one country to another, generally in the trade process. Many economists consider international trade as a balance of internal production capabilities with domestic demand. If the people of a country demand more of a certain product than their production capacity, then the shortage will be filled by importing it. Likewise, the occurrence of exports, if the amount of consumption of the product produced is smaller, it means that the excess is an exported product. (Bachrawi, 2015). Thus it can be concluded that export is one of the economic activities carried out by selling or removing goods from within the country and sent to other countries. Usually, this trade is carried out when a country produces these goods in large quantities. The obstacles faced in the export of commodities include:

a. Low competitiveness in price and delivery time.

b. Competitiveness is often considered an internal problem for exporters. In fact, it is a national problem that cannot be solved by entrepreneurs themselves.

c. Marketing channels do not develop overseas. 
In carrying out exports to foreign countries can be reached by:

a. Ordinary export: goods are sent abroad following applicable general regulations, addressed to overseas buyers to fulfill transactions previously held with importers abroad.

b. Barter: delivery of goods abroad to be exchanged directly for goods needed domestically. Barter can be further divided into Direct Barter, Switch Barter, Counter Purchase, and Buy-Back Barter.

c. Consignment: delivery of goods abroad for sale while the proceeds from the sale are treated the same as ordinary exports.

d. Package deal: this is a kind of barter but the goods to be exported are agreed upon trade agreement form.

e. Smuggling: trade carried out by individuals or business entities abroad for their interests regardless of the community interests. Smuggling is carried out by violating the law (illegal) or administrative smuggling by piggybacking on legal procedures.

\subsection{Currency Exchange Rates}

In economics, there are two types of exchange rates: nominal exchange rates and real exchange rates [8]. The price difference between two currencies is known as the nominal exchange rate. The actual exchange rate, on the other hand, is the price difference between the two countries' goods, or the rate at which we can trade goods from one country for commodities from another. The real exchange rate can be used to determine the terms of trade. According to Thobarry (2009), there are two approaches used to determine currency exchange rates, namely the monetary approach and the market approach [12]. In the monetary approach, the currency exchange rate is defined as the price at which foreign currency is traded against the domestic currency and this price is related to the supply and demand for money.

Depreciation and appreciation are terms used to describe changes in currency rates. Depreciation is when the value of a country's currency falls against the value of other countries' currencies; appreciation is when the value of a country's currency rises against the value of other countries' currencies. The depreciation of a country's currency lowers the price of its commodities for foreign parties if all other variables remain constant (ceteris paribus). Meanwhile, assuming all other conditions remain the same, a country's currency appreciation causes the price of its goods to rise for overseas buyers [13].

\subsection{Fashion Industry}

Etymologically, fashion comes from the Latin "factio" which means "to do." In its development, the word derived from Latin was absorbed into English into "fashion" which is then simply defined as a style of clothing that is popular in culture. According to Oxford Advanced Learner's Dictionary of Current English, fashion is defined as "prevailing custom; that which is considered must be admired and imitated during a period at a place." This sentence has the meaning, general habit; which is considered to be admired and followed for a certain period and in a certain place.

According to the Cambridge Dictionary, fashion means "style that is popular at a particular time, especially in clothes, hair, make-up, etc." The sentence has the meaning of a style that is popular at a certain time, especially in clothes, hairstyles, make-up, etc. According to the Big Indonesian Dictionary, fashion has the meaning of the latest variety of ways or forms (fashion styles, haircuts, patterns, and so on) within a specific time. Therefore, fashion can change and change rapidly over time. The study of fashion is not only about clothing, but also the 
meaning and role of clothing in social action. Fashion can be interpreted as a social skin that carries the message and lifestyle of a particular community and even a part of social life and in principle fashion cannot be separated from people's taste factors which are influenced by certain socio-cultural developments.

According to Pauline Watson in Fashion Era (2007), for centuries every individual or society has worn clothes or other body decorations as a means of non-verbal communication that indicates profession, gender, household status, social class, and level of wealth. Fashion is a form of freedom to express thoughts, feelings and is also a sign language and symbols that nonverbally communicate about an individual or group. Then, fashion is one of the things that distinguish one individual from another, because clothes, accessories, and other body decorations are very easy to be noticed by others in an instant. At first, a fashion trend must get a positive response from the community, then the fashion trend can become epidemic and be imitated by everyone because of the competition that has indirectly been raised by the fashion. Examples of fashion trends that are currently being enjoyed in Indonesia are hijabers, where they create their hijabs with an attractive appearance.

According to Simmel, fashion has two tendencies, the first is the need to unite, and the second is the need to be isolated. Every individual who consumes fashion needs to be able to merge with the society where he is located, and on the other hand, individuals who consume fashion also need to be or appear different in their community group. People need to be social and individual at the same time, and fashion and clothing are ways of negotiating complex desires or demands. According to Simmel, interaction arises because of particular interests and impulses. One form of interaction that Simmel talks about is fashion. A style is a form of social relations that wants people to conform to the wishes of the group. Style is dialectical which means that success and the spread of style will lead to failure. Positive things that arise from interactions can occur through the establishment of community solidarity, and negative things are in the form of conflicts. Simmel's interest in this form of interaction drew a lot of criticism. He is accused of forcing an order that does not exist and of producing unrelated studies which ultimately do not apply a better order to social reality at all. According to its form, there is a concept called Subordination (obedience) and Superordination (domination).

\subsection{Inflation}

Inflation is defined in many different ways, but they all cover the same points. Samuelson (2001) defines inflation as a condition where there is an increase in the general price level, both for goods, services, and factors of production [14]. The definition indicates a decline of purchasing power followed by a decline in the real (intrinsic) value of a country's currency. Meanwhile, another definition asserts that inflation occurs when there is an imbalance (disequilibrium) between aggregate demand and supply, which is greater aggregate demand than aggregate supply. In this case, the general price level reflects the relationship between the flow of goods or services and the flow of money. If the flow of goods is greater than the flow of money, deflation will occur, otherwise, if the flow of money is greater than the flow of goods, the price level will rise and inflation will occur.

In general, economists conclude that inflation causes a decrease in the purchasing power of the value of money for goods and services, the size of which is determined by the elasticity of demand and supply for goods and services. Other factors that also determine fluctuations in the general price level include government policies regarding price levels, namely by holding price controls, providing subsidies to consumers, and so on. From the existing definition of inflation, it can be drawn three points contained (Gunawan, 1991), namely: 
a. There is a tendency for prices to increase, which means that the price level that occurs at a specific time may decrease or increase compared to before, but still shows an increasing trend.

b. The price increase is continuous, not just one time.

c. Includes the general level of prices, which means that the increased price level is not only for one or a few commodities.

According to Rahardja and Manurung (2004) an economy is said to have experienced inflation if the following three characteristics are met, namely: 1) there is an increase in prices; 2) the increase in prices in general; 3) it is continuous. Several indicators can be used to determine whether an economy is being hit by inflation or not [15]. These indicators include:

a. Consumer Price Index (CPI), the CPI is the most commonly used price index as an indicator of inflation. The CPI represents the prices of goods and services consumed by the public in a certain period.

b. Wholesale Price Index (IHPB), the IHPB is an indicator that describes the price movements of commodities traded at the producer level in an area during a certain period. If the CPI observed is the final goods consumed by the public, in the IHPB it is observed that raw goods and semi-finished goods are inputs for producers.

c. GDP Deflator, the basic principle of the GDP deflator is to compare the nominal economic growth rate with real growth.

\subsection{Banking Edit}

The term credit comes from the Latin "credere" ("credo" and "creditum") that all mean trust. That it can be said in this connection, the creditor or the party providing credit (the bank) in a credit relationship with the debtor (credit recipient customer) has confidence that the debtor within the time and on mutually agreed terms can repay the credit in question. The definition of credit as stated in the Banking Law Number 10 of 1998 is the provision of money or bills that can be equated with it, based on a loan agreement or loan agreement between a bank and another party that requires the borrower to repay his debt after a certain period with interest [16]. Credit is all types of loans that must be repaid with interest by the borrower following the agreed agreement [16].

\subsection{Tourist}

In general, tourism is a trip that is carried out by a person for a while which is carried out from one place to another by leaving the original place and with a plan or not to earn a living in the place he visited, but solely to enjoy sightseeing or recreational activities. to fulfill various desires. According to Kodhyat (2010) tourism is a journey from one place to another, temporary in nature, carried out by individuals or groups, as an effort to find balance or harmony and happiness with the environment in the social, cultural, natural, and scientific dimensions. While Gamal (2010) defined tourism as a form of a temporary departure process from a person, more towards another place outside his place of residence. The impetus for his departure was due to various interests, including economic, social, cultural, political, religious, health, and other attractions.

Furthermore, Burkart and Medlik (1987) describe tourism as a temporary and short-term transformation of people to destinations outside the places where they usually live and work, and their activities during their stay at those destinations. According to the WTO (1999), what 
is meant by tourism is a human activity that travels to and lives in a destination outside of their daily environment. Based on some of the definitions of tourism above, it can be concluded that tourism is "a travel activity carried out by one or more persons held in a short period from one place to another, with the intention of sightseeing or recreation." In addition, it can be said that people who travel on a tour will need various goods and services from the time they go from their place of origin to their destination and return to their place of origin.

\subsection{Research Position}

Sourced from the relevant research table in Tedjo Asmoro's Dissertation (2021), it can be summarized that the position of this research is a follow-up study on the effect of the rupiah exchange rate, the number of fashion industries, inflation, banking credit, and tourism on the export performance of creative industry products in the fashion sector. This research produces new findings where the 5 (five) determinant variables on the export performance of creative industry products in the fashion sector, the Number of Fashion Industries is the variable that most dominantly affects the export performance of the fashion industry compared to other variables. It shows how important it is for this sector to continue to grow and develop in massive numbers. It is based on the fact that the fashion industry in Indonesia is currently growing pretty quickly. In addition, the fashion industry is still one of the largest foreign exchange earners for Indonesia because fashion products dominate the export portion for the creative economy sector. Thus, the findings in this study are novelty or state of the art compared to previous studies.

\subsection{Framework}

This study is intended to analyze how the influence of the rupiah exchange rate, the number of the fashion industry, inflation, banking credit, and tourism on the export of creative industry products in the fashion sector. The influence between variables in this study is depicted in Figure 1 below:

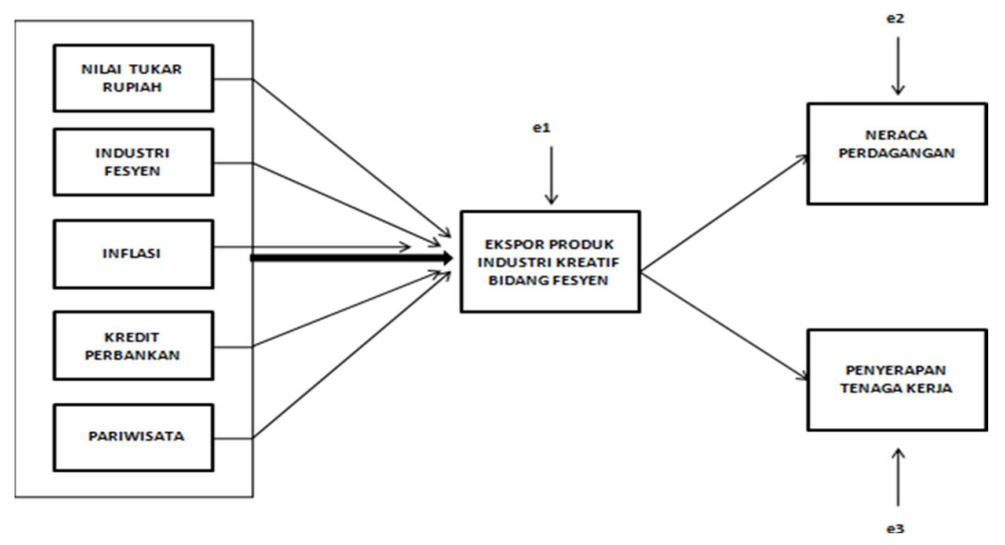

This paradigm of thought is a synthesis of a theoretical review that reflects the relationship between the variables studied and is a guide for solving research problems and formulating hypotheses. 


\subsection{Hypothesis}

Based on the framework of thought, problem formulation, and research objectives, the research hypotheses are as follows:

a. The rupiah exchange rate, the number of fashion industries, inflation, bank credit, and tourism affect the export of creative industry products in the fashion sector.

b. The rupiah exchange rate has a positive effect on the export of creative industry products in the fashion sector.

c. The number of fashion industries has a positive effect on the export of creative industry products in the fashion sector.

d. Inflation negatively affects the export of creative industry products in the fashion sector.

e. Banking credit has a positive effect on the export of creative industry products in the fashion sector.

f. Tourism has a positive influence on the export of creative industry products in the fashion sector.

\subsection{Data Collection Technique}

The data used in this study is secondary data, namely data in the form of quarterly/quarterly reports that compiled and published by related parties, in the form of time series data for 11 years, from 2010 to 2020. Institutional institutions related to the data required are; Central Statistics Agency, National Development Planning Agency, Bank Indonesia, Ministry of Tourism \& Creative Economy Agency, Ministry of Trade, Ministry of Industry Ministry of Manpower.

\subsection{Variable Operational Definition}

Variable operational limitations in this study are needed, to avoid mistakes in drawing conclusions.

\begin{tabular}{|c|c|c|c|}
\hline Variable & Conceptual Definition & Operational Definition & Data Types \\
\hline $\begin{array}{l}\text { Export of Creative } \\
\text { Industry Products } \\
\text { in fashion }(\mathrm{Y})\end{array}$ & $\begin{array}{l}\text { Various kinds of goods and } \\
\text { services produced by the creative } \\
\text { industry in the fashion sector } \\
\text { domestically and then sold } \\
\text { abroad (Mankiw, 2012). }\end{array}$ & $\begin{array}{l}\text { Indonesian Fashion } \\
\text { Industry Export Data } \\
2010-2020 \text { Ministry of } \\
\text { Trade and Ministry of } \\
\text { Tourism and Creative } \\
\text { Economy }\end{array}$ & Ratio \\
\hline $\begin{array}{l}\text { Rupiah Exchange } \\
\text { Rate (X1) }\end{array}$ & $\begin{array}{l}\text { The price of one country's } \\
\text { currency relative to another } \\
\text { country's currency. (Yoopi } \\
\text { Abhimanyu, 2014) }\end{array}$ & $\begin{array}{l}\text { Central Exchange Rate } \\
\text { and JIBOR Data for } \\
2010-2020 \text { from Bank } \\
\text { Indonesia }\end{array}$ & Ratio \\
\hline $\begin{array}{l}\text { Number of } \\
\text { Fashion Industry } \\
\text { (X2) }\end{array}$ & $\begin{array}{l}\text { Creative activities related to the } \\
\text { creation of clothing designs, } \\
\text { footwear designs, and other } \\
\text { fashion accessories designs, } \\
\text { production of fashion clothing } \\
\text { and accessories, consulting } \\
\text { fashion product lines, and } \\
\text { distribution of fashion products. }\end{array}$ & $\begin{array}{l}\text { Data on the Number of } \\
\text { Fashion Industry in } \\
\text { Indonesia in } 2010-2020 \\
\text { Ministry of Industry and } \\
\text { Central Statistics Agency }\end{array}$ & Ratio \\
\hline
\end{tabular}




\begin{tabular}{|c|c|c|c|}
\hline Variable & Conceptual Definition & Operational Definition & Data Types \\
\hline & (Bekraf, 2013) & & \\
\hline Inflation $\left(\mathrm{X}_{3}\right)$ & $\begin{array}{l}\text { Economic events that often } \\
\text { happen even though we never } \\
\text { want to. Inflation is everywhere } \\
\text { and is always a monetary } \\
\text { phenomenon that reflects } \\
\text { excessive and unstable monetary } \\
\text { growth (Dornbusch and Fischer, } \\
\text { 2001). }\end{array}$ & $\begin{array}{lrr}\text { National Inflation } & \text { Data } \\
\text { for 2010-2020 } & \text { Bank } \\
\text { Indonesia and } & \text { the } \\
\text { Central Bureau } & \text { of } \\
\text { Statistics. } & & \end{array}$ & Ratio \\
\hline $\begin{array}{l}\text { Banking Credit } \\
\left(\mathrm{X}_{4}\right)\end{array}$ & $\begin{array}{l}\text { Provision of money or equivalent } \\
\text { claims, based on an agreement or } \\
\text { loan agreement between the bank } \\
\text { and another party that requires } \\
\text { the borrower to repay the debt } \\
\text { after a certain period of time } \\
\text { with interest. (Banking Law No. } \\
\text { 10/1998) }\end{array}$ & $\begin{array}{l}\text { Banking Credit Data for } \\
\text { the clothing industry } \\
2010-2020 \text { Bank } \\
\text { Indonesia and the } \\
\text { Central Bureau of } \\
\text { Statistics }\end{array}$ & Ratio \\
\hline Tourism $\left(\mathrm{X}_{5}\right)$ & $\begin{array}{l}\text { The whole network and the } \\
\text { symptoms associated with the } \\
\text { stay of foreigners in a place, } \\
\text { provided that they do not stay } \\
\text { there to do an important job that } \\
\text { provides permanent or temporary } \\
\text { benefits (Hunzieker and K. } \\
\text { Krapf in Muhammad Ilyas, } \\
\text { 2009) }\end{array}$ & $\begin{array}{l}\text { Data on the Number of } \\
\text { Foreign Tourists who } \\
\text { came to Indonesia in } \\
2010-2020 \\
\text { Ministry of Tourism and } \\
\text { the Central Statistics } \\
\text { Agency }\end{array}$ & Ratio \\
\hline
\end{tabular}

\subsection{Model Formulation}

This study uses multiple linear regression analysis, namely regression in which the model has more than one explanatory variable, namely several independent variables are used to explain the behavior of the dependent variable. The regression analysis technique in this study used the Ordinary Least Square (OLS) technique. Multiple linear regression equation:

$\mathrm{Y}=\mathrm{b} 0+\mathrm{b} 1 \mathrm{X} 1+\mathrm{b} 2 \mathrm{X} 2+\mathrm{b} 3 \mathrm{X} 3+\mathrm{b} 4 \mathrm{X} 4+\mathrm{b} 5 \mathrm{X} 5+\mathrm{t}$

Information:

b0 ...n $=$ Constant Equation 1 to $\mathrm{n}$

$1 \ldots . n=$ Standard Error equation 1 to $\mathrm{n}$

$\mathrm{Y} \quad=$ Export Performance

$\mathrm{X} 1=$ Rupiah Exchange Rate

$\mathrm{X} 2=$ Number of Fashion Industry

$\mathrm{X} 3=$ Inflation

X4 = Banking Credit

X5 = Tourism

\subsection{Research Design}

The research design used in this study is to analyze the time series data for the quarters of 2011 to 2020 using explanatory research analysis or hypothesis research through explanations. 
Explanatory research is an analytical tool to explain the causal relationship between variables by testing the hypothesis. The explanatory format is to describe a generalization or explain the relationship of one variable to another, therefore explanatory research uses hypothesis testing using inferential statistics (for hypothesis testing), according to Bungin's opinion [17].

\subsection{Statistical Analysis Techniques}

Data analysis techniques used in this study are inferential statistics and regression analysis. The research method according to the level of explanation of this research is associative research. Associative research is research that aims to determine the relationship between two or more variables. According to the type of data and analysis using the kinds of quantitative data [17]. The several analytical techniques used in this study are as follows:
a. Descriptive Statistics
b. Classical Assumption Test
c. Stationary Test (Unit Root Test)
d. Multiple Linear Regression Analysis
e. Statistical Hypothesis
f. Model Feasibility Test

\section{Results and Discussion}

\subsection{Statistical Results and Interpretation}

From the results of statistical processing carried out in the dissertation; Tedjo Asmoro (2021), the results and interpretations are as follows:

Dependent Variable: Ln_EXPORT Method: Least Squares

Date: 06/02/21 Time: 16:46 Sample: 2010Q1 2020Q4

Included observations: 44

Table 2. Multiple Linear Regression

\begin{tabular}{lcccc}
\hline \multicolumn{1}{c}{ Variable } & Coefficient & Std. Error & t-Statistic & Probability \\
\hline C & 10.30980 & 0.565676 & 18.22561 & 0.0000 \\
Ln_KURS & 0.155523 & 0.064134 & 2.424971 & 0.0202 \\
Ln_INDUSTRI & 0.293288 & 0.077368 & 3.790824 & 0.0005 \\
Ln_INFLASI & -0.089439 & 0.029423 & -3.039817 & 0.0043 \\
Ln_KREDIT & 0.147846 & 0.045640 & 3.239396 & 0.0025 \\
Ln_PARIWISATA & 0.034736 & 0.016733 & 2.075824 & 0.0447 \\
R-squared & 0.680776 & Mean dependent var & 8.833076 \\
Adjusted R-squared & 0.672457 & S.D. dependent var & 0.065741 \\
S.E. of regression & 0.050391 & Akaike info criterion & -3.011884 \\
Sum squared resid & 0.096492 & Schwarz criterion & -2.768586 \\
Log likelihood & 72.26145 & Hannan-Quinn criter. & -2.921657 \\
F-statistic & 7.037233 & Durbin-Watson stat & 1.718958 \\
Prob(F-statistic) & 0.000097 & & \\
\hline
\end{tabular}

Source: Processing data with Eviews 10

Calculation results in Table 2. can be presented the results of multiple linear regression are as follows:

$Y=10.30980+0.155523 X 1+0.293288 X 2-0.089439 X 3+0.147846 X 4+0.034736 X 5$ 
The interpretation of the regression equation is as follows:

a. Constant value $=10.30980$ means that statistically if all ceteris paribus variables have constant values, then the export value of creative industry products in the fashion sector is 10.30980 percent.

b. The value of the Regression Coefficient $\mathrm{b} 1=0.155523$, meaning that the elasticity of the exchange rate Rupiah against the US dollar against exports of creative industry products fashion field of $E=0.155523$. The value of $E<1$ indicates that the increase in the rupiah exchange rate against the US dollar is inelastic towards exports of creative industry products in the fashion sector.

c. The value of the Regression Coefficient b2 $=0.293288$, meaning that the elasticity value of the number of fashion industries to the export of creative industry products in the fashion sector is $E=0.293288$. The value of $E<1$ indicates that the increase in the number of the fashion industry is inelastic towards the export of creative industry products in the fashion sector.

d. The value of the Regression Coefficient b3 $=0.089439$, meaning that the value of the inflation elasticity of exports of creative industry products in the fashion sector is $\mathrm{E}=$ 0.089439 . The value of $\mathrm{E}<1$ indicates that the increase in inflation is inelastic towards the export of creative industry products in the fashion sector.

e. The value of the Regression Coefficient $b 4=0.147846$, meaning that the elasticity value of banking credit distribution to the export of creative industry products in the fashion sector is $\mathrm{E}=0.147846$. The value of $\mathrm{E}<1$ indicates that the increase in bank lending is inelastic in terms of exports of creative industry products in the fashion sector.

$\mathrm{f}$. The value of the Regression Coefficient of $\mathrm{b} 5=0.034736$, meaning that the value of tourism elasticity is moderate to exports of creative industry products in the fashion sector of $\mathrm{E}=0.034736$. The value of $\mathrm{E}<1$ indicates that the increase in tourism is inelastic towards the export of creative industry products in the fashion sector.

\subsection{Simultaneous F Test}

The F-statistical test is used to determine the relationship between the independent variables jointly affecting the dependent variable. The calculation results obtained in Table 4.7 are a significance value of 0.000970 .05 which means a significant effect, indicating that the variables of the Rupiah exchange rate against the US Dollar, the number of the fashion industry, inflation, banking credit distribution, and tourism simultaneously have a significant effect on product exports of fashion creative industry. Interpretation in the language of economics means significant meaning that the hypothesis of the Rupiah exchange rate against the US Dollar, the number of the fashion industry, inflation, banking credit, and tourism can be proven convincingly and significantly affect the export of creative industry products in the fashion sector.

\subsubsection{Partial Test of the Effect of The Rupiah Exchange Rate Against the US Dollar (X1) on the Export of Creative Industry Products in the Fashion Sector}

The t-test is done by looking at the level of significance or, in this study, the used is $5 \%$ or 0.05. Thus, based on Table 4.7 above, it can be concluded that the effect of the Rupiah exchange rate against the US Dollar on the export of creative industry products in the fashion sector based on the results of calculations obtained in the multiple linear regression table, 
statistically shows that the significance of the Rupiah against the US Dollar is smaller $=$ of (0.0202 0.05), it can be concluded that the variable exchange rate of the Rupiah against the US Dollar has a significant and positive effect on the export of creative industry products in the fashion sector. Interpretation in the language of economics means significant that the hypothesis of the Rupiah exchange rate against the US Dollar can be convincingly and meaningfully proven to affect the export of creative industry products in the fashion sector. Meanwhile, a positive understanding means that the increase in the exchange rate of the Rupiah against the US Dollar is also followed by an increase in exports of creative industry products in the fashion sector.

\subsubsection{Partial Test of the Effect of the Number of Fashion Industries (X2) on the Export of Creative Industry Products in the Fashion Sector}

The results of the calculations obtained by a multiple linear regression table, The Influence of the Number of Fashion Industries on the Export of Creative Industry products in the fashion sector, statistically shows the results of the significance of the Number of Fashion Industries being smaller than $(0.00050 .05)$. It can be concluded that the variable Number of Fashion Industries significant and positive effect on the export of creative industry products in the fashion sector. Interpretation in the language of economics means significant meaning that the hypothesis of the Number of Fashion Industries can be convincingly and meaningfully proven to affect the export of creative industry products in the fashion sector. Meanwhile, a positive understanding means that an increase in the number of fashion industries is also followed by an increase in the exports of creative industry products in the fashion sector.

\subsubsection{Partial Test of the Effect of Inflation (X3) on the Export of Creative Industry Products in the Fashion Sector}

The results of the calculations obtained by the multiple linear regression table, The Influence of Inflation on the Export of Creative Industry Products in the fashion sector, statistically shows the results of the significance of Inflation $=$ less than $(0.00430 .05)$, it can be concluded that the Inflation variable has a significant and negative effect on Exports Creative Industry Products in the fashion sector. Interpretation in the language of economics means significant that the inflation hypothesis can be convincingly and meaningfully proven to affect the export of creative industry products in the fashion sector. While the negative meaning implies that the increase in inflation is followed by a decrease in exports of creative industry products in the fashion sector.

\subsubsection{The Effect of Banking Loans (X4) on Exports of Creative Industry Products in the Fashion Sector}

The calculation results obtained by the multiple linear regression table, The Effect of Banking Credit Distribution on the Export of creative industry products in the fashion sector, statistically shows the significance of Banking Credit Distribution is smaller than $(0.0025$ 0.05), it can be concluded that the variable Banking Credit Distribution significant and positive effect on the export of creative industry products in the fashion sector. Interpretation in the language of economics means significant that the hypothesis of Banking Credit 
Distribution can be convincingly and meaningfully proven to affect the export of creative industry products in the fashion sector. Meanwhile, a positive understanding means that the increase in Banking Credit Distribution is also followed by an increase in exports of creative industry products in the fashion sector.

\subsubsection{The influence of Tourism (X5) on the Export of Creative Industry Products in the Fashion Sector}

The results of the calculations obtained by the multiple linear regression table, the influence of tourism on the export of creative industry products in the fashion sector, statistically shows the results of the significance of tourism $=$ less than $(0.04470 .05)$, it can be concluded that the tourism variable has a significant and positive effect on Exports of Creative Industry Products in the Fashion Sector. Interpretation in the language of economics means significant meaning that the Tourism hypothesis can be convincingly and meaningfully proven to affect the export of creative industry products in the fashion sector. While a positive understanding means that the increase in tourism is also followed by an increase in exports of creative industry products in the fashion sector.

\subsection{Coefficient of Determination (R-Squared)}

The magnitude of the influence of the Rupiah exchange rate against the US Dollar, the number of the fashion industry, inflation, banking credit distribution and tourism simultaneously have a significant effect on the export of creative industry products in the fashion sector, as indicated by the regression results of the five independent variables on the exports of creative industry products in the fashion sector, namely Adjusted R Squared = 0.672457 , means that the magnitude of the influence of the Rupiah exchange rate against the US Dollar, the number of the fashion industry, inflation, banking credit distribution and tourism simultaneously have a significant effect on the export of creative industry products in the fashion sector by 67.24 percent, the remaining 32.76 percent is influenced by other factors outside the model under study. While partially, in the regression results above, the variables with the greatest influence to the least influence are in the following order:

a. The number of fashion industries has the most dominant influence on the export of creative industry products in the fashion sector with a t-statistic value of 3.790824 and a significance value of 0.0005 .

b. Banking credit distribution has the second broadest influence on the export of creative industry products in the fashion sector with a t-statistic value of 3.239396 and a significance value of 0.0025 .

c. Inflation has the third-largest influence on the export of creative industry products in the fashion sector with a t-statistic value of 3.039817 and a significance value of 0.0043 .

d. The rupiah exchange rate against the US dollar has the fourth-largest influence on the export of creative industry products in the fashion sector, the t-statistic value is 2.424971, and the significance value is 0.0202 .

e. Tourism has the least influence on the export of creative industry products in the fashion sector, the t-statistic value is 2.075824 , and the significance value is 0.0447 . 


\subsection{Discussion and Implementation}

\subsubsection{The Influence of the Rupiah Exchange Rate against the US Dollar, the Number of the Fashion Industry, Inflation, Banking Credit Distribution, Tourism on the Export of Creative Industry Products in the Fashion Sector}

The fashion industry sector (textiles and apparel) is one of the priority industrial sectors in the Making Indonesia 4.0 program, so it is crucial to continue to develop it. Among the sixteen creative industry sub-sectors, fashion is the most potential industry. The contribution to Indonesia's GDP is also the largest among other creative industry sub-sectors. The contribution of the fashion industry to the trade balance also did not disappoint. Amid a current account deficit, the fashion industry's exports continued to grow quite significantly. The fashion industry is also the broadest contributor to creative industry exports with a proportion reaching 64 percent of the total creative industry exports.

The considerable potential of the fashion industry to answer problems in the Indonesian economy requires a better boost in improving its performance. Not only for the domestic market but also foreign markets, one of the targets of this industry is to make Indonesia the center of Asian fashion by 2025. The export performance of the finished fashion industry throughout 2020 has reached US\$ 10.62 billion. Meanwhile, its contribution to the GDP of the non-oil and gas processing industry is 6.76 percent. Fashion trends that exist in Indonesia reflect a reflection of social and economic status that is usually identified as popularity. Fashion has recently become a lucrative industry in Indonesia, seeing that its growth is always increasing. Based on data from CNBC Indonesia (2019), the development of the fashion industry was able to contribute around $18.01 \%$ or IDR 116 trillion.

According to data in 2017 , the fashion industry in Indonesia has contributed to the national Gross Domestic Product by 3.76 percent, with an export value of 13.29 billion US dollars. The fashion sub-sector in the creative economy was also the largest contributor in the previous year, 2016, as much as $54.54 \%$. More specifically, Indonesia as a country with the largest Muslim population in the world has the potential to dominate the world's Muslim fashion industry. The Muslim fashion industry is estimated to absorb 1.1 million workers from a total of 3.8 million workers in the fashion industry. Currently, Indonesia occupies the fifth position as the largest exporter of Muslim fashion in the world, after Bangladesh, Turkey, Morocco, and Pakistan.

So, it is very feasible for Indonesia to become the mecca of Muslim fashion in the world in 2021. The development of Muslim fashion in Indonesia has achievements in the international arena. It refers to the report of The State of Global Islamic Economy Report 2019/2020,[20] that Indonesia ranks third as a country that develops the best Muslim fashion in the world after the United Arab Emirates and Turkey. The State Global Islamic Economy Report 2019/2020 also revealed that the value of world Muslim fashion consumption reached US\$ 283 billion. Supported by a growth rate of $6 \%$, this value is estimated to continue to increase to reach US\$ 402 billion. Meanwhile, Indonesian Muslim fashion consumption reached US\$ 21 billion. It shows that the global and domestic Muslim fashion market opportunities are enormous and must be filled by the Indonesian Muslim fashion industry.

However, during the COVID-19 pandemic, it became a difficult time for all parties, including the Indonesian Muslim fashion industry players who are part of the apparel industry sector. Data from The State of Global Islamic Economy Report 2020-2021 that have been released reports that world Muslim fashion consumption in 2019 is estimated to reach 277 
billion US dollars. In 2020, the world's Muslim fashion consumption decreased slightly due to the Covid 19 pandemic, shrinking 2.9 percent to 268 billion US dollars.

The impact of the Covid 19 pandemic also impacted the projected number of world Muslim fashion consumption in 2024, which decreases to 311 billion US dollars, where before the pandemic, the figure reached 402 billion US dollars in 2024. Meanwhile, world Muslim fashion consumption in 2019, amounting to 16 billion US dollars. Referring to BPS data, Indonesia's fashion product exports experienced a significant decline. The total value of exports of products such as clothing, jewelry, watches, and footwear overall recorded a decrease. The decline occurred in 2019 where the export value for the four main commodities of the fashion world fell from US\$ 727 million to US\$ 664 million. The impact of the Covid19 pandemic then worsened the export conditions for Indonesian fashion products.

Therefore, the Indonesian fashion industry must change its strategy if it wants to remain active in the global market. Currently, he explained, fashion industry players must be able to create products that not only indicate quality and price, but also unique added values that reflect the cultural uniqueness of the country.

\subsubsection{The Effect of the Rupiah Exchange Rate against the US Dollar on the Export of Creative Industry Products in the Fashion Sector}

The creative industry can take advantage of economic opportunities from the rising exchange rate of the dollar against the rupiah, namely increasing the volume of exports. According to the World Bank, the movement of the rupiah exchange rate has a higher level of volatility than the previous year and tends to move higher than other currencies in Asia. It is indeed not a new economic phenomenon, but how big the impact of the movement of the rupiah exchange rate, especially on the dynamics of national exports and imports, needs to be studied in more depth. There are two prepositions on the impact of the movement of the rupiah exchange rate. First, the depreciation of the rupiah exchange rate has a positive impact on export demand so that the trade balance increases. Comparatively, Indonesian products will be cheaper than competing countries.

Leigh et al. (2016) estimate the impact of exchange rate depreciation at $10 \%$, which will cause an increase in the trade balance by an average of $1.5 \%$. Second, the depreciation of the rupiah exchange rate will harm the trade balance. It is due to the high content of imports in export-oriented industries so that the depreciation of the rupiah exchange rate reduces the ability to produce and export products to global markets. These two inconclusive expectations require empirical and accurate proof so that a valid answer regarding the impact of rupiah exchange rate movements can be obtained. Rose (1991) illustrates that the exchange rate does not affect the income balance in five OECD countries after the Bretton Woods era. Rose and Yellen (1989) cannot reject the hypothesis that the real exchange rate is not statistically significant in determining trade flows. They examine bilateral trade flows between the United States and other OECD countries using quarterly data. Arize et al. (2000) conducted a study on exchange rate volatility on foreign trade in 13 developing countries during 1973-1996. In general, it was found that exchange rate volatility harmed export demand both in the short term and in the long term.

Research conducted by Sabuhi Sabouni and Piri (2008) on the effect of volatility on exports of the agricultural sector showed different results. The volatility of the exchange rate turned out to have a positive impact in the long term on exports of the agricultural sector in Iran. The exchange rate can have positive and negative effects on exports. A positive effect occurs when the strengthening of the exchange rate can affect exports so that exports can 
increase. The exchange rate can affect the price of an exported good so that when the rupiah exchange rate against the dollar strengthens, the price of exported goods will rise. Mankiw (2012, p.67) explains that when the value of an item rises, the quantity demanded of the goodwill decrease. When the price falls, the quantity demanded will increase. The negative effect of the exchange rate occurs when the exchange rate weakens, so exports increase or increase. Sukirno (2017, p.408) explains that when the value of the rupiah decreases or there is a currency devaluation, exports will increase because, in foreign markets, the country's exports become cheaper.

Based on historical data on the movement of the Rupiah exchange rate, it can be identified that the Rupiah has shown a weakening tendency since 2013, with the peak occurring in July 2015 with a value of Rp. 14,657/USD. What happened also showed that this phenomenon continued in 2018 where the nominal exchange rate touched Rp. 14,400 as of mid-July 2018. Concerning the movement of the Rupiah exchange rate, Bank Indonesia (2018) stated that the relative weakening of the exchange rate against the USD was also experienced by regional countries. The movement of the Rupiah exchange rate can be said to be manageable, referring to the fact that the Rupiah weakened $-0.91 \%$, smaller than the weakening of currencies of peer countries such as Thailand Bath $-1.04 \%$ and Indian Rupee $-1.96 \%$.

Domestic companies conducting international trade expect the stability of the rupiah exchange rate against the dollar to predict their production and revenue levels. Exporters gain when the goods or services they market become cheaper in foreign markets. The weakening of the rupiah exchange rate does not always have a negative effect. The weakening of the rupiah can be a blessing for export activities. The weakening rupiah makes the prices of our products more competitive abroad so that domestic industries have the opportunity to boost exports. The weakening of the rupiah exchange rate caused the value of the goods from Indonesia in the export market to be cheaper. It means that competitiveness increases. The weakening of the rupiah is an opportunity to boost exports. The government must try to take advantage of the weakening of the rupiah to increase exports of the fashion industry. Thus, the trade balance deficit that has occurred so far can be suppressed.

\subsubsection{The Influence of the Number of Fashion Industries on the Export of Creative Industry Products in the Fashion sector}

The fashion industry in Indonesia is currently growing very rapidly. It is in line with the awareness of the Indonesian people about fashion that leads to a lifestyle. The enthusiasm of Indonesia's creative economy is strongly influenced by the development of the fashion industry which can contribute around $18.01 \%$ or Rp. 116 trillion. Currently, various fashion trends continue to develop, one of which is ready-to-wear or ready-to-wear clothing which carries a lot of fast fashion business concepts that have the character of fast fashion changes and low production costs in the fashion industry is one of the prioritized industries in the application of industry 4.0 in the future. So it is valid to say that the fashion industry has a central role in supporting the Indonesian economy in the future.

During the first three months (Q1), the growth of the textile and apparel industry was the highest at 18.98 percent. This achievement increased significantly compared to the same period in 2018 which was at 7.46 percent and also increased from the acquisition during 2018 of 8.73 percent. Meanwhile, data from the Central Statistics Agency (BPS) also shows that the large and medium manufacturing industries (IBS) production in the first quarter of 2019 rose 4.45 percent compared to the same period last year. 
This high growth is due to several factors, including broad investments in the upstream sector, especially rayon fiber producers. Then the import control policy carried out by the government since February 2017 also contributed to the decline in imports which reached 2.1 percent in the first quarter of 2019. The increase in IBS production was due to the clothing industry sector which skyrocketed to 29.19 percent due to the abundance of orders, especially from the export market.

Following the Making Indonesia 4.0 roadmap, the fashion industry wants to make national textile and apparel producers into the top five in the world by 2030 which will be carried out with several digital transformations to support the development of the textile industry. Our textile industry needs to transform by optimizing the uses of digital technology, such as 3D printing, automation, and the internet of things (IoT) to make this happen.

The Muslim fashion industry in Indonesia continues to grow, both in terms of increasingly diverse product variations and increasingly competitive product quality. Besides, the potential of the domestic market that is quite huge is making the fashion industry business still prospective in the future. West Java has become a reliable area in the basis of Indonesian fashion products. It happened in line with the Government's efforts to make Indonesia a mecca for Muslim fashion in the world. In West Java, there are Tasikmalaya, Bandung, and other areas have been well recognized for their Muslim fashion products. Besides West Java, there is also Central Java, which is now emerging for Muslim fashion products, such as Kudus. These two regions have become the basis for the emergence of Muslim fashion products, towards Indonesia to become the mecca of world Muslim fashion.

In recent years, the fashion industry, especially Muslim clothing in the country, has shown positive growth. It indicates an increase in its export performance and its contribution to national GDP. The government through the Ministry of Industry continues to spur the development of the Muslim fashion industry in the country to be more competitive in the global arena. This strategic effort is to show Indonesia's readiness to become one of the world's Muslim fashion centers. The State Global Islamic Economy reports that the world's Muslim fashion consumption currently reaches USD 270 billion, which is projected to continue to increase at a growth rate of 5\% so that in 2023 it will reach USD 361 billion.

Meanwhile, Muslim fashion consumption in Indonesia is at USD 20 billion with a growth rate of $18.2 \%$ per year. One thing that we are all proud of is the significant increase in Indonesia's achievements in the international world. According to data from The State of Global Islamic Economy Report 2018/2019, Indonesia is the runner-up country that develops the best Muslim fashion in the world after the United Arab Emirates. This achievement shows that Indonesia is one step closer to being in the first place and becoming one of the world's Muslim fashion centers.

Moreover, the Muslim fashion industry, which is part of the textile and textile product (TPT) sector, has a significant contribution to the national economy. National textile product exports reached USD13.27 billion in 2018 or grew 5.4\% compared to the previous year of USD12.59 billion. On the other hand, the performance of the textile industry has grown significantly, from $3.76 \%$ in 2017 to $8.73 \%$ in 2018 . Throughout $2018-2019$, by carrying out various development activities for the Muslim fashion industry involving as many as 656 fashion SMEs and 60 designers. Examples of programs are linking and matching the Muslim fashion industry with the textile industry, technical guidance and SKKNI certification, capacity building for Muslim fashion SMEs, as well as the growth and development of new Muslim clothing SMEs.

The Covid-19 pandemic has affected several industrial sectors, including the fashion industry. Business of Fashion noted that nearly three-quarters of registered fashion companies 
suffered losses. There was a sales decline of 34 percent in the January-March 2020 period when the Covid-19 pandemic had just exploded. At the end of the year, based on an analysis of the McKinsey Global Fashion Index (PDF), the profit rate fell by 90 percent compared to 2019. Throughout 2020, the fashion industry was threatened by the high risk of bankruptcy. Industry leaders must rack their brains to change strategies and new business models to survive. In the end, bitter choices were inevitable, starting from closing thousands of outlets around the world, firing employees, to canceling fashion shows.

The fashion industry is required to enter the digital realm to survive. It is considered that it will bring benefits in the progress of business and marketing in the community. Digitalization is also considered to be the key for the fashion industry to bounce back. Digitalization provides new optimism where 71 percent of fashion executives expect their fashion business to grow 20 percent or more in 2021. According to data from Fashion's Big Reset 2020 by Boston Consulting Group, fashion companies can increase 30 to 55 percent of total sales through digital applications. Sales increase can also be done through digitalization, for example, digital commerce.

\subsubsection{The Influence of Inflation on Exports of Creative Industry Products in the Fashion Sector}

Historically, the level and volatility of inflation in Indonesia have been higher than inflation in other developing countries. While other developing countries experienced an inflation rate of between 3-5 percent, per year, in the period 2005 - 2014, Indonesia had an average annual inflation rate of 8.5 percent in the same period. Only starting from 2015 , inflation in Indonesia can be said to be under control. It even entered a new era: the era of low inflation. The characteristics of the less stable inflation rate in Indonesia lead to larger deviations from the annual inflation projections by Bank Indonesia (compared to the deviation between inflation realization and central bank targets in other countries). The result of this kind of inflation ambiguity is the creation of economic costs, such as higher borrowing costs in this country (domestic and international) compared to other developing countries. Once a good track record of achieving annual inflation targets is established, greater monetary policy credibility will follow.

If you don't consider the price adjustments set by the government, there are two peaks of annual inflation that usually occur in Indonesia. The December-January period is always a time of rising prices due to Christmas and New Year's celebrations. In addition, frequent flooding in January (because of the peak of the rainy season) causes disruption of distribution lines in some areas and cities and therefore leads to higher logistics costs. Inflation has a negative relationship with exports, when inflation occurs, commodity prices will increase. The increase in commodity prices is caused by the production used to produce a commodity costing a lot of money. Expensive commodity prices will make these commodities unable to compete in the global market. Ball $(2015$, p.281) states that when the inflation rate is high, the prices of goods and services produced or offered by a country will increase so that these goods and services become less competitive, and exports will fall.

Besides having a negative effect, inflation can also have a positive effect on exports. The positive effect of inflation is that a country's exports can increase because capital from debt or loans to produce goods and services increases. It is following the opinion of Ball (2015, pp. 280-281), namely, when high inflation will encourage borrowing, the loan will be repaid with a lower value of money. Starting from 2015, when the rupiah's performance stabilized, inflation was low and the current account deficit was under control, Bank Indonesia could 
loosen its monetary policy and initiate a somewhat aggressive monetary easing process, reflected in lower benchmark interest rates (see table below). Bank Indonesia drastically lowered its benchmark interest rate from 7.75 percent in early 2016 to 4.25 percent in September 2017 (this also includes the change from the BI rate to the BI 7-day Reverse Repo Rate as the central bank's benchmark tool).

During the COVID-19 pandemic, the Government and Bank of Indonesia (BI) agreed on three strategic steps to strengthen inflation control and keep exports conducive.

First, maintaining volatile food inflation in the range of $3.0 \%$ to $5.0 \%$. Efforts are made to strengthen the four pillars of the strategy including price affordability, supply availability, smooth distribution, and effective communication (4K) during the Covid-19 pandemic, including maintaining supply availability and smooth distribution ahead of national religious holidays. Strategy implementation is focused on maintaining continuous supply over time and smooth distribution between regions, among others through the use of information technology and strengthening interregional cooperation.

Second, strengthening the coordination of the central and local governments in controlling inflation through holding the 2021 Inflation Control National Coordination Meeting (Rakornas) with the theme of encouraging the increasing role of food MSMEs through optimizing digitalization to support economic recovery and food price stability.

Third, strengthen the synergy between Ministries/Institutions (K/L) with the support of local governments to make the TPIP 2021 work program a success. Fourth, strengthen national food security by increasing production, including through the food estate program, as well as maintaining smooth distribution through optimization of infrastructure and efforts to deal with the impact of natural disasters. Fifth, maintain the availability of government rice reserves (CBP) in the context of the supply availability and price stabilization (KPSH) program to support the implementation of community activity restrictions (PPKM).

\subsubsection{The Effect of Banking Loans on Exports of Creative Industry Products in the Fashion Sector}

Banking is still one of the main sources of financing for the fashion industry sector. In 2019, financing sources from banking 2019 reached $71 \%$ of the total industrial sector financing. In the period of this research period from 2010 to 2020 , the creative sector, especially the fashion industry, slowly began to be ogled by the banking industry. This industry is predicted to be the main support for the Indonesian economy if commodities become unreliable in the future. There is a bright spot in terms of regulation, in the Trademark and Patent Copyright Law it is stated that intellectual property can be used as collateral with a fiduciary agreement. Banks are interested in providing financing. Because they are aware that there is great potential in the creative industry. However, on the other hand, they must also comply with regulations and uphold the principle of prudence.

The value or valuation of a creative product whose definition is not yet clear is a serious challenge for banks. Therefore, we need a particular institution that can provide value to innovative products. Through the Ministry of Tourism and Creative Economy, the government is seeking to have an intellectual property valuator institution so that the price of a creativitybased business can be estimated and deserve a loan from a bank. In addition, guarantee institutions such as Perum Jamkrindo can also be involved in this.

Currently, the number of medium and large business units included in the fashion industry sub-sector reaches around 8.2 percent (2474 units) of the total companies in the non-oil and gas manufacturing industry. The capital ownership structure of business units in the textile 
industry sub-sector is dominated by the national private sector ( 93 percent), with sources of capital coming from PMDN (23 percent), PMA (10 percent), and others (67 percent).

The utilization rate of the existing capacity is around 72.3 percent. Meanwhile, the number of medium and large business units included in the apparel industry sub-sector reached around 8.7 percent (2614 units) of the total companies in the non-oil and gas manufacturing industry. The capital ownership structure of business units in the apparel industry sub-sector is dominated by the national private sector ( 90 percent), with sources of capital coming from PMDN (19 percent), PMA (14 percent), and others (68 percent). The utilization rate of the existing capacity is around 84.8 percent (Ministry of Industry, 2020).

Related to the industrial sub-sector above, several studies can be used as a reference to see the financing needs in the industrial sub-sector, one of the financing cases for the fashion industry is the result of Bank Indonesia's research on the fashion industry. This study stated that the fashion industry financing pattern can come from entrepreneurs themselves, credit from non-governmental organizations, advances from large companies that order apparel from entrepreneurs, as well as from bank loans with very diverse proportions. Most entrepreneurs have funds to meet their working capital and investment needs. But they also actually need credit from banks, but entrepreneurs find it difficult because of obstacles in providing collateral/guarantees. For business financing with a makloon pattern, entrepreneurs usually receive a down payment of $30 \%$ of the order value and pay it off after the finished garments are finished.

The important role of the fashion industry is also evident from its contribution to Indonesia's exports. During the 2010-2014 period, the contribution of apparel exports to Indonesia's total non-oil exports tended to be stable at an average of $0.5 \%$ per year. Had experienced a decline in the contribution to total non-oil exports in the period 2011-2013, but there was an increase in the contribution again in 2014. Thus, the distribution or financing of bank credit plays an important role and greatly influences the increase in exports of the fashion industry to foreign countries.

\subsubsection{The Influence of Tourism on Exports of Creative Industry Products in the Fashion Sector}

Tourism is one of the important sectors and makes a positive contribution to the national economy. The most obvious contribution of this sector is to the country's foreign exchange earnings. The additional foreign exchange from the tourism sector has been supporting the strengthening of foreign exchange reserves. The strong position of foreign exchange reserves will in turn encourage the strengthening (appreciation) of the rupiah exchange rate against foreign currencies, especially against the US dollar (Nizar, 2012). The development of the tourism sector also has links with international trade (exports and imports). This is evidenced through various studies that have been conducted in several countries where the two sectors have a positive causality relationship. That is, the two sectors can influence each other [21].

So far, what can be done is only by observing the development of the two sectors based on statistics on international trade (exports and imports) and the number of foreign tourists visiting Indonesia. From the available data, it can be seen that the development of the tourism sector and international trade shows a unidirectional trend.

Another approach that is also often used to see the influence or relationship of trade with tourism is based on the motives of people to travel. According to Spillane (1994), people travel are driven by the desire to: (i) have fun (pleasure tourism); (ii) recreation (recreation tourism); (iii) sport (sports tourism); (iv) cultural tourism (cultural tourism); (v) for convention 
tourism; and (vi) for trading or business (business tourism). The motive considered most relevant to trade is business travel. Because this trip is professional and is usually related to work or position. The business tour is not only carried out by entrepreneurs or manufacturers, but also by exhibition visitors. Entrepreneurs/industrialists and exhibition visitors also act as consumers/buyers and sellers for particular products in the countries visited. Therefore, the success of a business trip will directly create the export and/or import flows in the next period (Nizar, 2012).

Since 2010, the trend of foreign tourists has shown an increase. Meanwhile, the trend of domestic tourists tends to fluctuate. The number of both foreign and domestic tourists visiting Bali in 2018 reached 15.83 million tourists. This number consisted of 9.8 million domestic tourists; an increase of 11.7 percent compared to the previous year. Meanwhile, foreign tourists (tourists) also rose 6.54 percent or reached 6.1 million tourists. From 2013-2019 every year the contribution of the tourism sector to the national economy continues to increase. Apart from that, coordination from all related parties is highly expected to bring the tourism sector back to life. With all these efforts, at least the tourism sector can be a good jump start for the national economic recovery, to be able to encourage international trade such as exports of the fashion industry which will also feel the impact.

\section{Conclusions and Suggestions}

\subsection{Conclusions}

a. The exchange rate of the rupiah against the US dollar, the number of the fashion industry, inflation, banking credit distribution, and tourism simultaneously have a significant effect on the export of creative industry products in the fashion sector.

b. The exchange rate of the rupiah against the US dollar has a significant and positive effect on the export of creative industry products in the fashion sector.

c. The number of fashion industries has a significant and positive effect on the export of creative industry products in the fashion sector.

d. Inflation has a significant and negative effect on the export of creative industry products in the fashion sector.

e. Banking credit has a significant and positive effect on the export of creative industry products in the fashion sector.

f. Tourism has a significant and positive effect on the export of creative industry products in the fashion sector.

\subsection{Suggestions}

a. The increase in the value of Indonesia's exports, especially fashion products and is a good momentum for the government to continue to maximize export opportunities for national products. The researcher suggests to the government, in this case, the Ministry of Trade continues to make efficient and creative proactive efforts, namely by holding virtual business matching activities for fashion products. Virtual business matching is one of the strategies to optimize the export potential of Indonesian fashion products in export destination countries such as the United States during the Covid-19 pandemic. It is time for the Indonesian government to boost Indonesia's export performance to 
potential export destination countries and prove that Indonesia has quality products at competitive prices.

b. Several things can be considered by the fashion industry in dealing with the weakening of the rupiah and the current instability of the Indonesian economy, first, increasing the content of local raw materials. Besides could reduce costs, using local raw materials shows an attitude of respect and love for domestic products. Second, for those who are already export-based, this is the right time to boost production volume. Of course, it must be accompanied by the calculation of consumer demand abroad. If this opportunity can be maximized, then the benefits of strengthening the dollar can be felt in the long term. Third, business actors must remain optimistic. That is because Indonesia is not the only country whose currency exchange rate has weakened against the dollar. Even developed countries also experienced a decline such as Japan, Canada, Europe to Australia.

c. To further increase the number of industrial business actors in the fashion sector, the Indonesian government is advised to further clarify regulations and provide facilities to Creative Industry players, especially the fashion sector. Because there are so many creative industries, especially the fashion sector, that are difficult for capital and managerial, at least the Government provides educational training for creative industry players and does not complicate existing regulations and permits. Because most permits in Indonesia are very difficult.

d. The magnitude of the impact of this inflation needs to make the fashion industry business actors plan to deal with inflation, especially for a company, where the structure and activities are complex related to many parties. It is starting with suppliers, consumers, communities, employees or workers, and many other parties. Therefore, the researcher suggests to the fashion industry players to carry out strategies to deal with inflation, including by implementing internal cost efficiency, while these internal costs such as electricity costs, administrative costs, and other types of costs. Then, reduce production costs, operational costs, and marketing costs. The three costs that are ineffective and unnecessary should be reduced. Next, do innovation and product diversities, because by doing innovation and variety, it is hoped that sales will continue to run.

e. The government is advised to issue several policies for disbursing bank credit to laborintensive and export-based corporate business actors, especially the fashion industry through the provision of guarantee facilities so that banks can increase their working capital credit exposure to business actors. This program aims to support the needs of the labor-intensive and export-based fashion industry corporations for additional working capital loans so that they can return to their maximum activities during the pandemic.

f. One of the factors that influence the increase in exports of fashion industry products in the tourism sector. Therefore, the concept of developing and promoting Indonesian tourism needs to be promoted, especially with the Great concept, which is a tourism area development approach that integrates components such as infrastructure, accessibility, connectivity, activities, facilities, hospitality, and market preferences. For tourism marketing strategy, the Indonesian government does it based on the DOT approach, namely Destination, Origin, and Time. The Destination approach is mostly focused on Great Bali, Great Jakarta, and Great Batam as the main entry points for Indonesian tourism for foreign tourists. 


\section{References}

[1] Howkins, J. The Creative Economy: How People Make Money from Ideas. Penguins Books, London. 2001

[2] Badan Pusat Statistik, Ekspor Ekonomi Kreatif 2010-2016. Jakarta

[3] Kementerian PPN/ Bappenas, Perkembangan Ekonomi Indonesia dan Dunia tahun 2013- tahun 2017

[4] Yani Ahmad, Gunawan Widjaya, Transaksi Bisnis Internasional (Ekspor Impor dan Imbal Beli),2014. Jakarta: PT. Raja Grafindo Persada.

[5] Ruin, Josef Eby. Audit Committee: Going Forward Towards Corporate Governance. Malaysian Institute of Corporate Governance (MICG). 2013

[6] Seyoum Belay. Export-Import Theory, Practices, and Procedures Second Edition, New York: The Hawoth Press. 2014

[7] Suranovic Steven. International Trade, Theory and Policy. Lectures Notes. The International Economics Study Centre. 2010

[8] Mankiw N Gregory, Makro Ekonomi. Penterjemah Fitria Liza dan Imam Nurmawan. Jakarta: Airlangga. 2013

[9] Irham dan Yogi. Ekspor di Indonesia. Cetakan Pertama. Jakarta: Pustaka Binaman. Pressindo. 2013

[10] Mudrajad Kuncoro, Dasar-Dasar Ekonomi Pembangunan. Yogyakarta: UPP STIM. 2015

[11] Todaro, Michael dan Smith C. Stephen. Pembangunan Ekonomi. Penterjemah Haris Munandar. Jakarta: Erlangga. 2018

[12] Thobarry Achmad, Ath. Analisis Pengaruh Nilai Tukar, Suku Bunga, Laju Inflasi Dan Pertumbuhan GDP Terhadap Indeks Harga Saham Sektor Properti (Kajian Empiris Pada Bursa Efek Indonesia Periode Pengamatan Tahun 2000-2008 ), Universitas Diponegoro Semarang. 2009

[13] Krugman, Paul R and Obstfeld Maurice. Ekonomi Internasional (Teori dan Kebijakan). Edisi Kedua. Jakarta: Manajemen PT Raja Grafindo Persada. 2006

[14] Samuelson, Paul A dan Nordhaus. Ilmu Makro Ekonomi. Penterjemah Greeta Theresa Tanoto, Bosco Carvallo dan Anna Elly. Jakarta: Gramedia Global Edukasi. 2006

[15] Rahardja dan Manurung, M,. Pengantar Ilmu Ekonomi (Mikroekonomi \& Makroekonomi). 2014. Jakarta: Lembaga Penerbit Fakultas Ekonomi Universitas Indonesia.

[16] Kasmir. Analisis Laporan Keuangan. 2016. Jakarta: Raja Grafindo Persada.

[17] Bungin Burhan. Metodologi Penelitian Sosial dan Ekonomi Format-Format Kuantitatif dan Kualitatif. 2013. Jakarta: Kencana Prenada Media Group

[18] Sugiyono. Metode Penelitian Bisnis. 2013. Bandung: Alfabeta.

[19] Sadono Sukirno. Ekonomi Pembangunan: Proses, Masalah, dan Dasar Kebijakan. 2014. Jakarta: PT. Rajagrafindo Persada

[20] Le Souk. State of the Global Islamic Economy Report. 2015

[21] Turner, L.W., and Witt, S.F. Forecasting Tourism Using Univariate and Multivariate Structural Time Series Models. 2001. Tourism Economics. Vol. 7 (2). pp 135-147.

[22] Sadono Sukirno. Pengantar Bisnis. Edisi Pertama. 2013. Jakarta: Kencana.

[23] Ari Mulianta Ginting. Perkembangan Neraca Perdagangan dan Faktor- faktor Yang Mempengaruhinya. Jurnal Buletin Ilmiah Litbang Perdagangan, Pusat 
Pengkajian, Pengolahan Data dan Informasi (P3DI), Bidang Ekonomi dan Kebijakan Publik, Vol. 8, No. 1, Juli 2014, hal. 56.

[24] Badan Pusat Statistik. Buletin Statistik Perdagangan Luar Negeri. Ekspor Jakarta 2017

[25] Badan Pusat Statistik. Nilai Tukar Valuta Asing di Indonesia. 2017. Jakarta

[26] Kementerian Perdagangan. Rencana Strategis (Renstra). Badan Pengkajian dan Pengembangan Perdagangan. 2017

[27] Lee Sin Yee, Har WaiMun, Tee Zhengyi, Lee Jie Ying, \& Khoo Kai Xin, Determinants of Export: Empirical Study in Malaysia. Journal of International Business and Economics June 2016, Vol. 4, No. 1, pp. 61-75 ISSN: 2374-2208(Print), 2374-2194(Online)

[28] Mudrajad Kuncoro. Manajemen Keuangan internasional. Edisi pertama. 2015. Yogyakarta: BPFE UGM

[29] Sudarsono. Pengantar Ekonomi Mikro. 1995. Jakarta : Pustaka LP3ES. 